\title{
Wading Bird Habitat, Water Depth Utilization and Niche Separation in Poyang Lake, China
}

\author{
Zhi Yijin, Shao Mingqin* and Li Quanjiang \\ College of Life Science, Jiangxi Normal University, Nanchang, Jiangxi, 330022, China
}

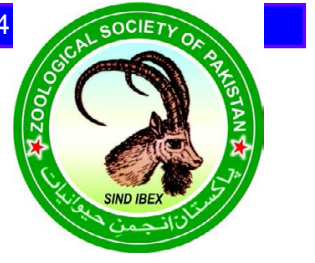

CrossMark

\begin{abstract}
A B S T R A C T
From October to December 2018, and March to May of 2019, habitat, water depth utilization and niche separation of wading birds in Poyang Lake, China, was assessed. A total of 38 bird species, including 4 class I and 3 class II Chinese nationally protected bird species were identified. Of six habitats, $64 \%$ $(15,435$ individuals $)$ of the total number of wading birds counted occurred in water-covered areas. The common crane Grus grus has the widest habitat niche (0.727), utilizing grasslands and farmland after crops were harvested, where it ate vegetation (roots) or seeds. Shorebirds have narrow habitat niches, and are limited largely to shallow water areas. Of species pairs, the pied avocet Recurvirostra avosetta and Eurasian spoonbill Platalea leucorodia have the highest habitat niche overlap, as their diet and foraging pattern are similar; these two species reduce competition by foraging in different areas. Three smallsized shorebirds are recorded in each water depth category. Both spotted redshank Tringa erythropus and common greenshank Tringa nebularia have high water depth niche breadth $(>0.7)$, with high tolerance to water level variation; both species segregate spatially to reduce competition. Of mid- and large-sized wading birds, the Eurasian spoonbill prefers V-grade waters and has a narrow water depth niche breadth. The water depth overlap of these mid- and large-sized wading birds ranged from 0 to 0.691 . Grey heron Ardea cinerea, Eurasian spoonbill, and the common crane are spatially or trophically separated in Poyang Lake. We conclude with suggestions for improved wading bird conservation and habitat management in and around Poyang Lake.
\end{abstract}

Article Information
Received 01 November 2019
Revised 11 February 2020
Accepted 20 February 2020
Available online 11 September 2020
Authors' Contribution
SMQ designed and revised the paper.
ZYJ, LQJ and SMQ collected and
analyzed the data. ZYJ wrote the
paper.
Key words
Habitat, Water bird, Niche breadth,
Niche overlap, Competition

\section{INTRODUCTION}

$\mathrm{T}$ he term niche refers to the temporal and spatial location of a population of a species in a natural ecosystem, and to mutual relationships between it and other populations (Hutchinson, 1959). This includes temporal, spatial and trophic niches, and reflects resource utilization and interspecific competition (Zeng and Qin., 2012). Studies on bird niches have examined resource utilization (Hino et al., 2002; Zhao et al., 2003), habitat selection (Zhao and Zhang, 2004; Tan et al., 2013), spatial distribution (Chen et al., 2009; Yu et al., 2011), and diet (Tan et al., 2013). Previous results showed coexisting birds can reduce their competition through temporal, spatial or trophic niche separation. Herons stagger foraging peaks and use different food resources to reinforce temporal and spatial niche separation (Tan et al., 2013). Elliot's Syrmaticus ellioti and silver pheasants Lophura nycthemera select habitats with different vegetation coverage to reduce competition (Chen et al., 2009).

Wetland was one of the most important ecosystems for biodiverstiy conservation. Recent reductions in wetland

\footnotetext{
* Corresponding author: 1048362673@qq.com 0030-9923/2020/0006-2233\$9.00/0

Copyright 2020 Zoological Society of Pakistan
}

area and quality threaten water bird populations (Chen, 2011). Hydrological condition is the main factor of attracting waterfowls, and variation of water depth had significant effects on wading birds (Hua et al., 2009; Mo et al., 2017). Some researchers showed transformation of ponds to paddy fields provided alternative habitats for some wading birds (Song and Zhou, 2019). Others thought the highest value of species richness and abundance of wintering water birds in fish ponds and reed is a strong support to the ecological restoration altering low-lying paddy fields to wetlands with fish ponds and reed (Zhao et al., 2003). So we should take various measures in different regions after we get more knowledge about the relationship between local birds and their environments. Poyang Lake is the largest fresh water lake in China. Each winter about 500-700,000 water birds migrate to Poyang Lake, where they reside for about 4-6.5 months (Che et al., 2018; Zhou et al., 2018). Studies on water birds in Poyang Lake focused on population size and distribution, time budget and foraging behaviors (Dai et al., 2014; Guo, 2016; Shao et al., 2018). However no data on habitat utilization and niche separation of wading birds in Poyang Lake have been reported. We aim to 1) describe habitat and water depth utilization of wading birds in Poyang Lake, and 2) analyze breadth and overlap niche in habitat and water depth of main wading bird species. 
By identifying how wading birds in Poyang Lake coexist, we believe suggestions for their conservation and habitat management can be advanced.

\section{MATERIALS AND METHODS}

\section{Survey area}

Poyang Lake is fed by the Ganjiang, Fuhe, Xinjiang, Xiuhe and Raohe rivers (Fig. 1), it has a subtropical climate, an annual average temperature of $17.6^{\circ} \mathrm{C}$ and 1450-1550 mm precipitation (Dai et al., 2014; Shao et al., 2018). Scattered mudflat, grassland and shallow water habitat provide abundant food and habitats for water bird species (Guo, 2016). Surveys were performed in Wuxing (14 sites), Henghu (12 sites) and Yugan reclamation farms (11 sites) (Fig. 1), where grassland, shallow water areas and mudflats represent main natural habitat types, with artificial habitats including rice land, lotus pond and fish ponds (Shao et al., 2018).

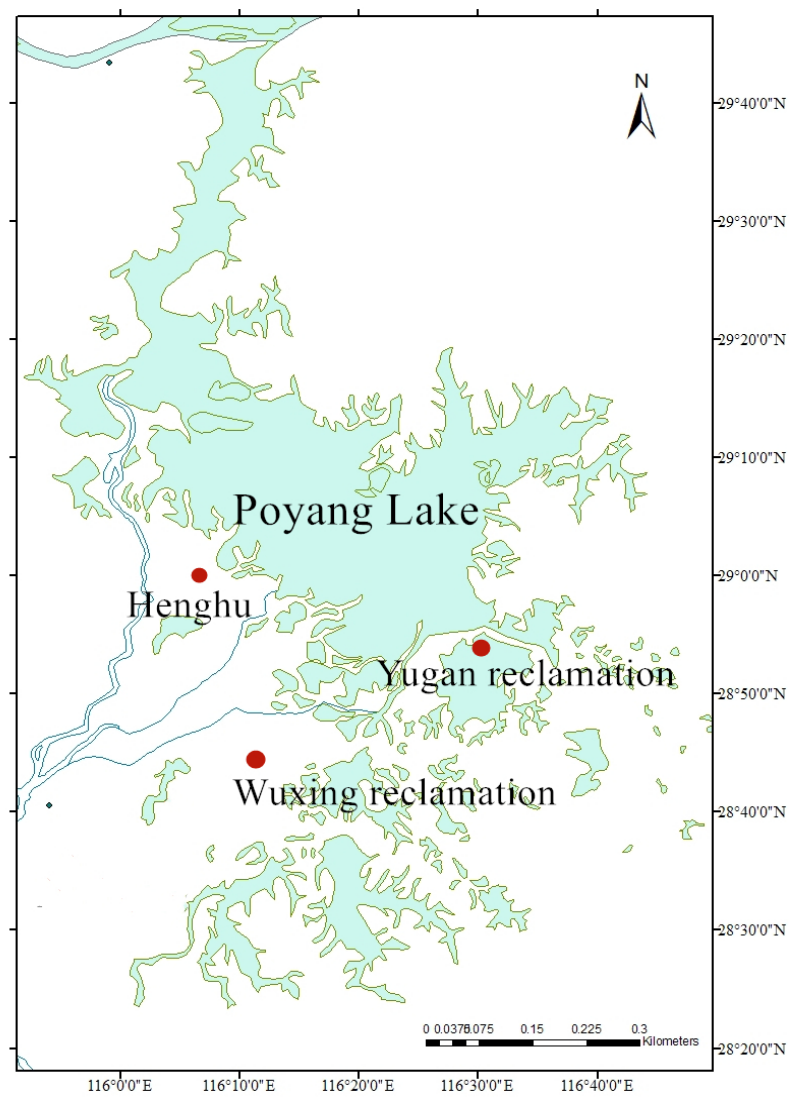

Fig. 1. Study area of wading birds in Poyang Lake.

\section{Bird surveys}

Wading birds were identified, counted, and their habitat and water depth was recorded by point count technique between October and December, 2018 and March and May, 2019. Birds were observed using a Swarovski monocular telescope $(20-60 \times 80 \mathrm{~mm})$ or Nikon binocular telescope ( $8 \times 42 \mathrm{~mm})$. At each observation site wading birds were counted for 10-20 min. Accurate (count birds one by one as the number of birds was small) and group counts (count the number of groups with 100 individuals as the wading birds form a big group) were combined. Bird taxonomy were according to the literature (Zheng, 2017). Species representing more than $5 \%$ were considered dominant (Jiang, 2016). Wintering habitats were classified as natural (water-covered areas, grassland, mudflat, and wasteland) or artificial (farmland and fish ponds) (Table I). Water depth for wading birds was grouped into five categories based on their leg length: I ( $<1 / 3$ tarsus), II (1/3-2/3 tarsus), III (2/3-1 tarsus), IV (tarsus to $<1 / 2$ tibia) and $\mathrm{V}(>1 / 2$ tibia) (Table II). According to the average leg length of birds in China, we could determine the water depth wading birds inhabit (Zhao, 2001).

Table I. Habitat types and description of wading birds in Poyang Lake.

\begin{tabular}{ll}
\hline Habitat type & Description \\
\hline $\begin{array}{l}\text { Water-covered } \\
\text { area }\end{array}$ & $\begin{array}{l}\text { Deep (depth } \geq 50 \mathrm{~cm} \text { ) and shallow (depth }<50 \\
\mathrm{~cm} \text { ) water area }\end{array}$ \\
Mudflat & Mud substratum, without surface water \\
Grassland & Land covered by grass \\
Wasteland & $\begin{array}{l}\text { Land either side of roads, often covered in } \\
\text { grass or dry soil, or land without crops beside } \\
\text { farmland }\end{array}$ \\
& $\begin{array}{l}\text { Mainly rice land, and a small area of lotus pond } \\
\text { Farmland }\end{array}$ \\
Pond & Fish ponds \\
\hline
\end{tabular}

Data analysis

(1) Niche breadth (Zhu et al., 1998)

$$
\mathrm{H}=-\left(\sum_{i} P_{i} \log _{2} P_{i}\right) / \mathrm{H}_{\max } \quad \ldots(1)
$$

$\mathrm{H}$ represents niche breadth, $P i$ represents the $i^{\text {th }}$ resource grade account for the total resource grades.

(2) Niche overlap (Zhu et al., 1998)

$$
\operatorname{Axy}(\mathrm{D})=1-\frac{1}{2} \sum_{i=1}^{n}\left|P_{x i}-P_{y i}\right| \quad \ldots(2)
$$

$P_{x i}$ and $P_{y i}$ represent the proportion of the $i^{\text {th }}$ resources grade for species $x$ and $y$ for the total resource (two dimensions: habitats and water depth), respectively. Axy (overlap value) ranges from 0 (no overlap) to 1 (complete overlap).

Niche breadth and overlap are measured using habitat (water, grassland, mudflat, wasteland, farmland and fish pond) and water depth. Water depth niche breadth is 
Table II. The corresponding range of inhabiting water depths for wading birds.

\begin{tabular}{llllll}
\hline Species & \multicolumn{5}{c}{ Water depth category (cm) } \\
\cline { 2 - 6 } & I & II & III & IV & V \\
\hline $\begin{array}{l}\text { Spotted redshank, } \\
\text { Tringa erythropus } \\
\begin{array}{l}\text { Common greenshank, } \\
\text { Tringa nebularia }\end{array}\end{array}$ & $0-1.80$ & $1.81-3.60$ & $3.61-5.40$ & $5.41-7.20$ & $7.21-8.60$ \\
$\begin{array}{l}\text { Wood sandpiper, } \\
\text { Tringa glareola }\end{array}$ & $0-2.00$ & $2.01-4.00$ & $4.01-6.00$ & $6.01-7.60$ & $7.61-9.20$ \\
$\begin{array}{l}\text { Oriental stork, } \\
\text { Ciconia boyciana }\end{array}$ & $0-1.20$ & $1.21-2.40$ & $2.41-3.70$ & $3.71-4.80$ & $4.81-5.90$ \\
$\begin{array}{l}\text { Eurasian spoonbill, } \\
\text { Platalea leucorodia }\end{array}$ & $0-8.30$ & $8.31-16.70$ & $16.71-25.00$ & $25.01-35.00$ & $35.01-45.0$ \\
$\begin{array}{l}\text { Grey heron, } \\
\text { Ardea cinerea } \\
\text { Common crane, }\end{array}$ & $0-4.80$ & $4.81-9.60$ & $9.61-14.40$ & $14.41-19.20$ & $19.21-24.00$ \\
Grus grus & $0-4.90$ & $4.91-9.90$ & $9.91-14.80$ & $14.81-19.70$ & $19.71-24.60$ \\
\hline & $0-7.70$ & $7.71-15.50$ & $15.51-23.20$ & $23.21-31.50$ & $31.51-39.70$ \\
\hline
\end{tabular}

measured based on the five categories of leg length; niche overlap in water depth is based on actual water depth. We found common crane has the largest inhabting water depth (about $36.2 \mathrm{~cm}$ ) among all mid- or large-sized wading birds. So we divided $36.2 \mathrm{~cm}$ into five categories and put the actual water depth of all mid- or large-sized birds into the corresponding water depth categories. We divided $8.4 \mathrm{~cm}$ (the largest inhabting water depth of small sized wading birds) into five categories and put the actual water depth of small-sized wading birds into the corresponding water depth categories. Only wading birds for which more than 30 individuals were counted are included in niche overlap analysis (Table II).

(3) Similarity index

$$
S=2 c /(a+b)
$$

$S$ represents the similarity index, $a$ is the number of species recorded in habitat $\mathrm{A}, b$ is the number of species in habitat $\mathrm{B}$, and $c$ is the number of species common to habitats $\mathrm{A}$ and $\mathrm{B}$.

\section{RESULTS}

\section{Species composition}

A total of 38 species belonging to eight families in four bird orders were recorded (Table III). Of these the Siberian crane Grus leucogeranus, hooded crane G. monacha, black stork Ciconia nigra, and oriental stork C. boyciana, are endangered and considered national class I protected birds in China, while the endangered white-naped crane Grus vipio, common crane G. grus and Eurasian spoonbill Platalea leucorodia, are considered national class II protected birds in China. Of these 38 species, $21(55.26 \%)$ belong to the order Charadriiformes, followed by $10(26.32 \%)$ to the order Pelecaniformes. The common coot Fulica atra, common crane, pied avocet Recurvirostra avosetta, spotted redshank Tringa erythropus, oriental stork, Eurasian spoonbill, and grey heron Ardea cinerea, were all dominant wading birds (Table III).

\section{Habitat utilization, separation and overlap niche}

The Little Egret Egretta garzetta was the only species to occur in all six habitats. Some species, such as the Siberian and common cranes, Northern Lapwing Vanellus vanellus, spotted redshank, and common greenshank Tringa nebularia, occurred in four or five habitats. Thirteen species occurred in one habitat only. Of the six habitats, wading birds (15,435 individuals, $64 \%$ of all wading birds) were most abundant in water-covered habitats. Wasteland (35 individuals) and fish ponds (178 individuals) had the least number of individuals (Table III).

The similarity index of six groups $>0.50$ is presented in Table IV. Of all habitats, water-covered area and grassland are most similar (0.708), and mudflats and wasteland least similar $(0.125)$.

The common crane (0.727), northern Lapwing (0.637), common sandpiper Actitis hypoleucos (0.670), and cattle egret Bubulcus ibis (0.640) have wide niche breadths (Table III), while 19 species have narrow niche breadths; of these 19 species, the niche breadth of 11 species (e.g., brown crake, and hooded and white-naped cranes) was zero (Table III).

Thirteen species pairs of 21 species pairs had a niche overlap exceeding 0.60 . The niche overlap of the pied avocet and Eurasian spoonbill (0.999), spotted redshank 
Table III. Wading bird numbers and distribution in Poyang Lake habitats.

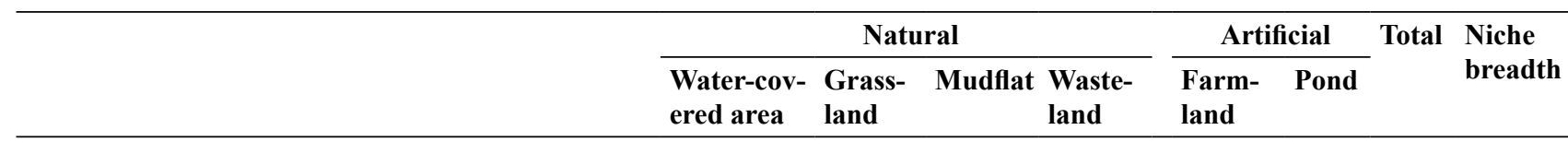

\section{Order: Gruiformes}

\section{Family Rallidae}

1. Brown Crake, Zapornia akool

2 Common moorhen, Gallinula chloropus

3 Common coot, Fulica atra

$\begin{array}{lll} & & 2 \\ 94 & 4 & \\ 1328 & 106 & \\ & & \\ 21 & 635 & \\ & 9 & \\ 415 & 2181 & 159 \\ & 6 & \end{array}$

\section{Family Gruidae}

4. Siberian grane, Grus leucogeranus

5. White-naped grane, Grus vipio

6. Common crane, Grus grus

7. Hooded crane, Grus monacha

\section{Order: Charadriiformes}

\section{Family Recurvirostridae}

8. Black-winged stilt, Himantopus himantopus

9. Pied avocet, Recurvirostra avosetta

\section{Family Charadriidae}

10. Northern lapwing, Vanellus vanellus

11. Grey-headed lapwing, Vanellus cinereus

$\begin{array}{ll}146 & 122 \\ 3 & \end{array}$

12. Pacific golden plover, Pluvialis fulva

13. Long-billed plover, Charadrius placidus

14. Kentish plover, Charadrius alexandrines

\section{Family Scolopacidae}

15. Common snipe, Gallinago gallinago

16. Asian dowitcher, Limnodromus semipalmatus

17. Black-tailed godwit, Limosa limosa

18. Whimbrel, Numenius phaeopus

19. Spotted redshank, Tringa erythropus

20. Common greenshank, Tringa nebularia

$\begin{array}{lll} & 1 & \\ 2920 & 824 & 50 \\ 105 & & 26 \\ 3 & & \\ 5 & & \end{array}$

21. Green sandpiper, Tringa ochropus

23. Terek sandpiper, Xenus cinereus

24. Common sandpiper, Actitis hypoleucos

25. Little stint, Calidris minuta

\section{Order: Ciconiiformes}




\begin{tabular}{|c|c|c|c|c|c|c|c|c|}
\hline & \multicolumn{4}{|c|}{ Natural } & \multicolumn{2}{|c|}{ Artificial } & \multirow{2}{*}{ Total } & \multirow{2}{*}{$\begin{array}{l}\text { Niche } \\
\text { breadth }\end{array}$} \\
\hline & $\begin{array}{l}\text { Water-cov- } \\
\text { ered area }\end{array}$ & $\begin{array}{l}\text { Grass- } \\
\text { land }\end{array}$ & Mudflat & $\begin{array}{l}\text { Waste- } \\
\text { land }\end{array}$ & $\begin{array}{l}\text { Farm- } \\
\text { land }\end{array}$ & Pond & & \\
\hline 28. Black stork, Ciconia nigra & 1 & 10 & & & & & 11 & 0.170 \\
\hline 29. Oriental stork, Ciconia boyciana & 1150 & 521 & 45 & & & & 1716 & 0.405 \\
\hline \multicolumn{9}{|l|}{ Order: Pelecaniformes } \\
\hline \multicolumn{9}{|l|}{ VII Family Threskiornithidae } \\
\hline 30. Eurasian spoonbill, Platalea leucorodia & 4575 & 2 & 2 & & & & 4579 & 0.004 \\
\hline \multicolumn{9}{|l|}{ VIII Family Ardeidae } \\
\hline 31. Black-crowned night heron, Nycticorax nycticorax & 11 & 1 & & 30 & 6 & 78 & 126 & 0.578 \\
\hline 32. Chinese pond heron, Ardeola bacchus & 5 & 1 & & & 8 & & 14 & 0.489 \\
\hline 33. Cattle egret, Bubulcus ibis & 2 & 1 & & 3 & 7 & & 13 & 0.640 \\
\hline 34. Grey heron, Ardea cinerea & 904 & 699 & 46 & & & & 1649 & 0.443 \\
\hline 35. Purple heron, Ardea purpurea & 4 & 5 & & & & & 9 & 0.383 \\
\hline 36. Great egret, Ardea alba & 86 & 183 & & & 3 & & 272 & 0.380 \\
\hline 37. Intermediate egret, Ardea intermedia & 16 & 5 & & & 45 & 1 & 67 & 0.483 \\
\hline 38. Little egret, Egretta garzetta & 576 & 78 & 20 & 1 & 31 & 31 & 737 & 0.464 \\
\hline Total & 15435 & 5421 & 496 & 35 & 2551 & 178 & 24116 & \\
\hline
\end{tabular}

and oriental stork (0.892), and oriental stork and grey heron $(0.822)$ was high, while that of the common crane and other wading species was low (Table V).

Table IV. The number of common species (above diagonal), similarity index (below diagonal) of wading birds in different habitats of Poyang Lake.

\begin{tabular}{lllllll}
\hline & $\begin{array}{l}\text { Water-cov- Grass- Mud- Waste- Farm- Pond } \\
\text { ered area }\end{array}$ & $\begin{array}{l}\text { land } \\
\text { flat }\end{array}$ & $\begin{array}{l}\text { land } \\
\text { land }\end{array}$ \\
\hline $\begin{array}{l}\text { Water-cov- } \\
\text { ered area }\end{array}$ & & 17 & 10 & 4 & 15 & 11 \\
Grassland & 0.708 & & & & & \\
Mudflat & 0.526 & 0.471 & & 1 & 6 & 6 \\
Wasteland & 0.258 & 0.231 & 0.125 & & 4 & 3 \\
Farmland & 0.600 & 0.522 & 0.333 & 0.286 & & 10 \\
Pond & 0.564 & 0.343 & 0.480 & 0.352 & 0.541 & \\
\hline
\end{tabular}

Water depth utilization, separation and overlap niche

The common greenshank (35.48\%), wood sandpiper Tringa glareola $(\sim 85 \%)$ and oriental stork $(\sim 78 \%)$ all prefer category III water depths (Table VI). Spotted redshank $(\sim 50 \%)$, Eurasian spoonbill $(\sim 98 \%)$ and grey heron $(\sim 67 \%)$ all prefer category $\mathrm{V}$ water depths. The common crane $(\sim 63 \%)$ prefers category II water depth. The spotted redshank $(0.761)$ and common greenshank $(0.880)$ have wide niche breadth, while that of the Eurasian spoonbill (0.062) is narrow (Table VI).

Of small-sized wading birds, the spotted redshank and common greenshank had the highest niche overlap (0.789), while the wood sandpiper and spotted redshank (0.201) and wood sandpiper and common greenshank (0.279), had the lowest. Of middle- or large-sized wading species, and the oriental stork and Eurasian spoonbill had zero niche overlap. The grey heron and Eurasian spoonbill (0.691), common crane and grey heron (0.650), and the oriental stork and common crane $(0.619)$ had high niche overlap, while that of the grey heron and oriental stork (0.309) was low.

\section{DISCUSSION}

\section{Habitat utilization and niche separation}

Water bird distribution is affected by many factors, such as their foraging behavior and resource availability (Zhu et al., 2007). We report wading birds to prefer resource (food) rich water-covered habitat and grassland around Poyang Lake. Wading birds with wide niches utilize diverse habitats and foods. The common crane has a wide niche and lives in grassland where it eats roots or seeds of vegetation, and farmland after the crops have been harvested. The omnivorous Northern Lapwing also has a wide niche and consumes insects, fish and seeds (Zhao, 2001). Shorebirds with narrow niches are restricted to specific habitats; the likes of the Black-tailed Godwit 
Table V. Niche overlap of seven dominant wading birds in different habitats of Poyang Lake.

\begin{tabular}{|c|c|c|c|c|c|c|c|}
\hline & $\begin{array}{l}\text { Common } \\
\text { coot }\end{array}$ & $\begin{array}{l}\text { Common } \\
\text { crane }\end{array}$ & $\begin{array}{l}\text { Pied } \\
\text { avocet }\end{array}$ & $\begin{array}{l}\text { Spotted } \\
\text { redshank }\end{array}$ & $\begin{array}{l}\text { Oriental } \\
\text { stork }\end{array}$ & $\begin{array}{l}\text { Eurasian } \\
\text { spoonbill }\end{array}$ & $\begin{array}{l}\text { Grey } \\
\text { heron }\end{array}$ \\
\hline \multicolumn{8}{|l|}{ Common coot } \\
\hline Common crane & 0.166 & & & & & & \\
\hline Pied avocet & 0.696 & 0.091 & & & & & \\
\hline Spotted redshank & 0.770 & 0.340 & 0.741 & & & & \\
\hline Oriental stork & 0.744 & 0.421 & 0.670 & 0.892 & & & \\
\hline Eurasian spoonbill & 0.696 & 0.092 & 0.999 & 0.742 & 0.671 & & \\
\hline Grey heron & 0.622 & 0.054 & 0.492 & 0.714 & 0.822 & 0.493 & \\
\hline
\end{tabular}

Limosa limosa, Curlew sandpiper Calidris ferruginea, and little stint Calidris minuta have narrow niches and occur in single habitats (shallow water), where they prey on benthic animals (Zhao, 2001).

The pied avocet and Eurasian spoonbill have high niche overlap, forage in water habitat, have a similar diet and foraging behaviors and use their bills to sweep for foods such as insects, benthic animals and plankton (Xie et al., 1995). The pied avocet is smaller and tends to gather in large groups (sometimes $>2000$ individuals) in water areas separate from the Eurasian spoonbill, thereby reducing competition. The common coot and other shorebirds such as pied avocet (0.696) and spotted redshank (0.770) have high niche overlap, but the common coot prefers deeper-water habitats, where it forages by diving (Zhao, 2001). As such, the niches of the common coot and other shorebirds are spatially separated.

Table VI. Distribution and niche breadth of seven wading species in different water depth grades in Poyang Lake.

\begin{tabular}{llllllllll}
\hline & \multicolumn{4}{c}{ Water depth } & & Total & $\begin{array}{l}\text { Niche } \\
\text { breadth }\end{array}$ \\
\cline { 1 - 5 } & I & II & III & IV & V & & & \\
\cline { 1 - 5 } Spotted redshank & 4 & 19 & 46 & 10 & 80 & 159 & 0.761 \\
Common greenshank & 2 & 7 & 11 & 2 & 9 & 31 & 0.880 \\
Wood sandpiper & 6 & 27 & 342 & 15 & 11 & 401 & 0.374 \\
Oriental stork & 1 & 12 & 46 & & & 59 & 0.365 \\
Eurasian spoonbill & & & & 2 & 96 & 98 & 0.062 \\
Grey heron & 1 & 6 & 10 & 1 & 37 & 55 & 0.599 \\
Common crane & & 24 & 14 & & & 38 & 0.414 \\
\hline
\end{tabular}

\section{Water depth utilization and niche separation}

Three small-sized shorebirds (spotted redshank, wood sandpiper and common greenshank) occurred in every water depth grade. Water depth niche breadth of the spotted redshank and common greenshank exceeded
0.7 , indicating a wide water depth tolerance. Because of their similar morphology and diet the spotted redshank and common greenshank have high niche overlap (0.789), but their niches are spatially separated. Spotted redshank are dominant shorebirds in Poyang Lake and tend to gather in large groups in lake, rice land and shallow fish pond habitats. The common greenshank is less common, and usually occurs as solitary individuals or in small groups, foraging in lake, river, and rice land habitat. Common greenshanks often occur in shallow river areas where the spotted redshank is seldom seen.

The preferred water depth of wading birds is related to their diets, foraging behaviors, ect. (Jiang, 2016). Of mid- and large-sized wading birds, the Eurasian spoonbill prefers foraging in V-grade water depths. Its water depth niche breadth $(0.062)$ is less than three other mid- to largesized wading birds. Eurasian spoonbills use their long bill to prey on plankton and mollusks, which occur at certain water depths (Zhao, 2001), but the relationship between prey abundance, water depth, and depth at which birds feed requires further investigation (Zhao, 2001; Chen, 2011).

Wading birds use different foraging behaviors and foods for effective resource utilization, and to minimize competition (Tan et al., 2013; Novcic, 2016). Grey heron and Eurasian spoonbill have high water depth niche overlap and tend to forage in water of about 19-25 cm depth, but while the grey heron preys on fish, the Eurasian spoonbill prefers plankton and mollusks (Zhao, 2001). Accordingly, competition is minimized by their having different diets. The common crane and grey heron also have high water depth niche overlap, but the grey heron mainly forages on fish in water-covered areas, resting in water-covered areas or on grassland, while the common crane eats plant material and prefers grassland, rice land and mudflat habitat and only seldom forages in watercovered areas. Harvested rice land around lakes represents an ideal habitat for common crane (Zhao, 2001; Jiang, 2016). These two species use different habitats and have 
different diets, minimizing competition, facilitating their coexistence.

\section{CONCLUSION AND SUGGESTIONS}

Our results demonstrate that wading birds prefer water-covered habitats, and shorebirds mainly forage in natural shallow water areas. Shorebirds also forage in farmland and ponds habitat, with shallow water area and shoals. To satisfy habitat requirements: 1) appropriate shallow water, muddy areas of $0.1-9.2 \mathrm{~cm}$ water depth should be provided to attract shorebirds; 2) some rice should be left as a food resource on farmland to attract common cranes, a national class II protected bird in China; and 3) deep-water habitats should be established or conserved to increase environmental heterogeneity for common coots and some larger-sized wading bird species.

\section{ACKNOWLEDGEMENT}

We thank Steve O'Shea $\mathrm{PhD}$ from Edanz Group (www.edanzediting.com/ac) for editing a draft of this manuscript. Funding for this project was provided by Chinese Natural Sciences Fund and Jiangxi Provincial Natural Sciences Fund (31860611, YC2019-S120,31560597).

\section{Statement of conflict of interest}

The authors have declared no conflict of interest.

\section{REFERENCES}

Che, Y.J., Jiang, M.X. and Zhong, Y.X., 2018. The study on temporal and spatial variation of ecosystem service value in Poyang Lake ecological economic zone based on the variation of land utilization. $J$. Jiangxi Norm. Univ. (Nat. Sci.), 42: 45-51.

Chen, J.Y., 2011. Study on community structure of waterbirds wintering at the lakes in Yangtze River floodplain in Anhui Province. Anhui University.

Chen, J.H., Huang, X.F., Lu, C.H., Yao, X.H. and Yu, Z.P., 2009. Spatial niches of Syrmaticus ellioti and Lophura nycthemera in autumn and winter. Chinese J. Ecol., 28: 2546-2552.

Dai, N.H., Shao, M.Q., Jiang, J.H. and Guo, H., 2014. The preliminary study on bird diversity during non-breeding period of Poyang Lake region in Gongqingcheng city. J. Jiangxi Norm. Univ. (Nat. Sci.), 38: 19-25.

Guo, H., 2016. Preliminary study on wintering ecology of the oriental white stock (Ciconia boyciana) and two Anseriformes birds in Poyang Lake. Jiangxi
Normal University.

Hino, T., Unno, A. and Nakano, S., 2002. Prey distribution and foraging preference for tits. Ornithol. Sci., 1: 81-87. https://doi.org/10.2326/ osj.1.81

Hua, N., Ma, Z.J., Ma, Q., Song, X.G., Tang, C.D., Li, B. and Chen, J.K., 2009. Waterbird use of aquacultural ponds in winter at Chongming Dongtan. Acta Ecol. Sin., 29: 6342-6350.

Hutchinson, G.E., 1959. Homage to Santa Rosalia or why are there so many kinds of animals. Am. Natural., 93: 145-159. https://doi.org/10.1086/282070

Jiang, J.H., 2016. Study on abundance and distribution of wintering water birds and ecological habits of four crane species in Poyang Lake. Jiangxi Normal University.

Mo, Y.M., Xie, H.B., Li, B., Zhang, W., Tang, G.C., Niu, D.L. and Wang, T.H., 2017. Community characteristics and habitat analysis of wintering waterfowls between different manage patterns of rice paddy in Chongming Dongtan. Chinese $J$. Zool., 52: 583-591.

Novcic, I., 2016. Niche dynamics of shorebirds in Delaware Bay: Foraging behavior, habitat choice and migration timing. Acta Oecol., 75: 68-76. https://doi.org/10.1016/j.actao.2016.07.002

Shao, M.Q., Gong, H.L., Dai, N.H., Zhi, Y.J., Xu, N. and Lu, P., 2018. Study on time budgets and behavioral rhythm of wintering Siberian cranes in a lotus pond reclamation area in Poyang Lake. Acta Ecol. Sin., 38: 5206-5212. https://doi.org/10.5846/ stxb201706131074

Song, Y.W. and Zhou, L.Z., 2019. Effects of habitat changes on spatio-temporal pattern of the wintering waterbrid community at Shengjin Lake. J. Anhui Agric. Univ., 46: 610-617.

Tan, F., Lin, Y.H. and Zhang, M.H., 2013. Feeding and nest site niche separation during the breeding period of Ardeid birds in Zhangjiang Estuary, Fujian Province, China. Chinese J. Wildl., 34: 7983.

Xie, Q.M., Li, Y. and Xiong, G.G.,1995. Studies on the ecology of zoobenthos and the estimation of bottom-fish productivity in Poyang Lake. Jiangxi Sci., 13: 161-170. https://doi.org/10.1007/978-3642-80046-7_6

Yang, X.T., Niu, J.Y., Luo, Z.K., Zhang, M., Tang, C.D. and Wang, T.H., 2013. The impact of natural succession process on waterbird community in an abandoned fishpond at Chongming Dongtan, China. Acta Ecol. Sin., 33: 4050-4058. https://doi. org/10.5846/stxb201207110978 
Yu, C.X., Yang, G., Li D. and Zhou, F., 2011. Ecological distribution and spatial niche of pheasants in the Karst mountains of southwest Guangxi Province, China. Zool. Res., 32: 549-555.

Zeng, C.H. and Qin, X.B., 2012. Spatial niche of rodents in summer in sino-Singapore Tianjin eco-city. Chinese J. Wildl., 33: 64-66.

Zhao, L. and Zhang, X.A., 2004. Nest-site selection and competition coexistence of horned larks and small skylarks. Zool. Res., 25: 198-204.

Zhao, P., Yuan, X., Tang, S.X. and Wang, T.H., 2003. Species and habitat preference of waterbirds at the eastern end of Chongming island (Shanghai) in winter. Zool. Res., 24: 387-391.

Zhao, Z.J., 2001. Chinese birds. Jilin Science and Technology Press, Changchun.

Zheng, G.M., 2017. A checklist on the classification and distribution of the birds of China. Science Press, Beijing.

Zhou, Y.X., Li, Y.K., Shan, J.H., Tu, X.B., Wei, Z.H., Shao, R.Q. and Zhang, N., 2018. The species diversity of water birds in the five river-catchment of Poyang Lake. J. Jiangxi Norm. Univ. (Nat. Sci.), 42: 571-577.

Zhu, J., Jing, K., Gan, X.J. and Ma, Z.J., 2007. Food supply in intertidal area for shorebirds during stopover at Chongming Dongtan, China. Acta Ecol. Sin., 27: 2149-2159. https://doi.org/10.1016/S18722032(07)60045-6

Zhu, X., Zhang, L.X., Liang, J. and Xuan, Z.C., 1998. Spatial niche and interspecific relationships of Ardeidae birds in Taigongshan hill, Zhejiang. Zool. Res., 19: 14-51. 